\title{
KETUPAT DESA ALASMALANG BANYUWANGI: MENGGALI MATEMATIKA DALAM BUDAYA
}

\author{
Husnul Hotima ${ }^{1}$, Rachmaniah M. Hariastuti ${ }^{2 *}$ \\ ${ }^{1,2}$ Program Studi Pendidikan Matematika Fakultas MIPA,Universitas PGRI Banyuwangi \\ Jalan Ikan Tongkol 22, Kertosari, Banyuwangi, Indonesia \\ e-mail: ${ }^{1}$ hotimkeling@gmail.com; ${ }^{2}$ mirzarachmania@gmail.com; \\ Submitted: February 14, 2021 \\ Revised: May 4, 2021 \\ Accepted: May 8, 2021 \\ corresponding author*
}

\begin{abstract}
Abstrak
Ketupat merupakan salah satu makanan tradisional yang dikenal oleh masyarakat Indonesia. Desa Alasmalang Kecamatan Singojuruh Kabupaten Banyuwangi merupakan salah satu daerah yang masih aktif melestarikan budaya Kupatan, yaitu perayaan hari ketujuh setelah hari raya Idul Fitri. Sayangnya, tradisi yang sarat dengan pembelajaran ini masih sekedar tradisi tanpa eksplorasi konsep-konsep pembelajaran di dalamnya. Untuk itu dilakukan eksplorasi etnomatematika dalam ketupat, khususnya ketupat bawang dan ketupat Jawa, yang biasa dibuat di Desa Alasmalang. Penelitian dilakukan dengan prinsip kualitatif berbasis etnografi dengan 3 orang informan yaitu Ibu-ibu di Desa Alasmalang. Pengumpulan data dilakukan dengan cara observasi dan wawancara. Analisis data ditentukan berdasarkan analisis domain dan analisis taksonomi untuk menemukan tema budaya. Hasil penelitian menunjukkan bahwa dalam ketupat bawang dan ketupat Jawa termuat konsep hubungan antar garis, sudut, geometri dua dimensi, geometri tiga dimensi, pengubinan, volume bangun ruang dalam satuan tidak baku, serta pecahan.
\end{abstract}

Kata Kunci: etnomatematika, ketupat bawang, ketupat Jawa

\section{KETUPAT ALASMALANG VILLAGE, BANYUWANGI: EXPLORING MATHEMATICS IN CULTURE}

\begin{abstract}
Ketupat is one of the traditional foods known by the Indonesian people. Alasmalang Village is one of the areas in Banyuwangi that is still active in preserving the Kupatan culture, which is the celebration of the seventh day after Eid. Unfortunately, this tradition which is full of learning is still just a tradition without exploration of the learning concepts in it. For this reason, ethnomathematical exploration was carried out in ketupat, especially ketupat bawang and ketupat Jawa, which are usually made in Alasmalang Village. The research was conducted using qualitative based on ethnography with 3 informants, that is women in Alasmalang Village. Data collection was done by observation and interviews. Data analysis was determined based on domain analysis and taxonomic analysis to find cultural themes. The results showed that the ketupat bawang and ketupat Jawa contained the concept of the relationship between lines, angles, twodimensional geometry, three-dimensional geometry, teselasi, volume with non-standard units, and fractions.
\end{abstract}

Keywords: ethnomathematics, ketupat bawang, ketupat Jawa 


\section{Pendahuluan}

Indonesia merupakan negara yang memiliki beragam makanan tradisional. Salah satu makanan tradisional yang cukup terkenal di Indonesia adalah ketupat. Makanan ini terdapat di berbagai daerah dengan nama dan tampilan yang beragam.

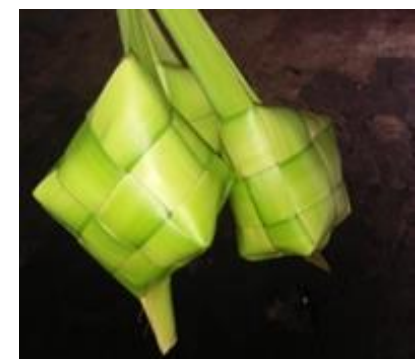

Gambar 1. Ketupat

Masyarakat Bali mengenal ketupat sebagai Tipat. Warga di Kota Makassar mengenal ketupat sebagai Katupa. Di Madura ketupat lebih dikenal sebagai Katopak, di Minangkabau dikenal sebagai Katupek, di Betawi dikenal sebagai Tupat, sedangkan di Banyuwangi tetap disebut ketupat.

Keberadaan ketupat sebagai makanan yang menjadi bagian dari kehidupan masyarakat Indonesia, khususnya pada saat hari raya Islam, menjadikan ketupat bukanlah hal asing dalam kehidupan masyarakat di Indonesia. Sayangnya ketupat masih sebatas menjadi bagian dari hidangan yang dapat dinikmati, tetapi belum menjadi bagian dari pembelajaran.

Ketupat merupakan makanan khas berbahan baku beras yang dibungkus dengan anyaman janur/daun kelapa berbentuk segi empat kemudian dimasak dalam air mendidih (Amin, 2017; Rahmadi, Sugiyono, \& Suyatna, 2019). Kupatan merupakan salah satu tradisi yang masih dilestarikan masyarakat Banyuwangi, khususnya di Desa Alasmalang Kecamatan Singojuruh. Tradisi ini biasa dilaksanakan pada hari ketujuh setelah Hari Raya Idul Fitri.

Kupatan atau hari raya Ketupat merupakan penanda berakhirnya pelaksanaan ibadah puasa dalam bulan Ramadhan dan telah selesainya pelaksanaan ibadah puasa sunnah enam hari di bulan Syawal (Djojosuroto, 2013; Arif \& Lasantu, 2019) Filosofi masyarakat Jawa menyebutkan bahwa ketupat bukan hanya sekedar hidangan khas hari raya, namun memiliki makna khusus yang merupakan singkatan dari Ngaku Lepat, yang berarti mengakui kesalahan, dan Laku Papat, yang artinya empat tindakan yang seharusnya dilakukan pada hari raya, yaitu lebaran, luberan, leburan, dan laburan (Yanti, 2019).
Ketupat sebagai makanan tradisional memiliki proses pembuatan yang cukup panjang dan unik. Proses tersebut diawali dari menganyam janur menjadi kulit/sarang ketupat, mengisi kulit ketupat dengan beras sebanyak sepertiga hingga duapertiga kulit ketupat, kemudian merebus ketupat dalam waktu \pm 5 jam (Rianti, et al., 2018). Lebih lanjut dijelaskan, jika pengisian beras terlalu sedikit akan menyebabkan ketupat memiliki tekstur yang lembek. Sedangkan jika terlalu banyak beras yang diisikan ke dalam kulit menyebabkan ketupat memiliki tekstur yang keras.

Belum banyak referensi yang membahas tentang ketupat, walaupun makanan tradisional ini merupakan makanan yang dikenal hampir di seluruh Indonesia. Secara umum dikenal duabelas bentuk ketupat, yaitu: ketupat jago, ketupat tumpeng, ketupat sidalungguh, ketupat sari, ketupat bata, ketupat debleng, ketupat sidapurna, ketupat bebek, ketupat geleng, ketupat bage, ketupat pandawa, dan ketupat gatep (Dwi \& Farabi, 2017). Walaupun demikian tidak setiap daerah mengenal dan menggunakan semua variasi ketupat tersebut.

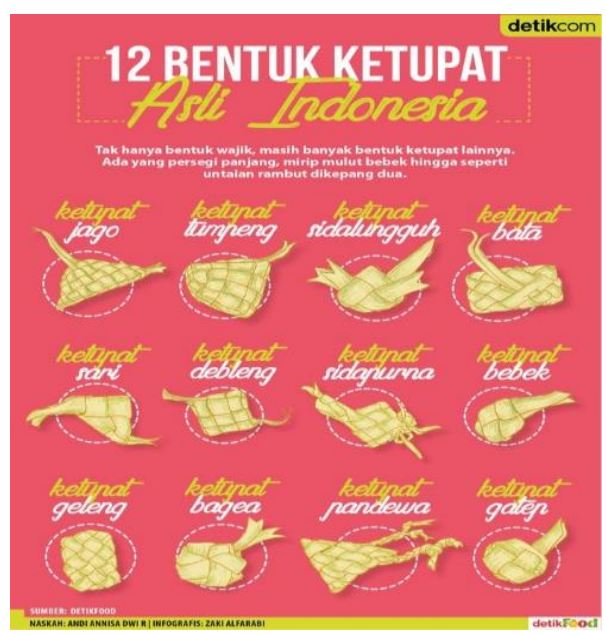

Gambar 2. Variasi Bentuk Ketupat (Dwi \& Farabi, 2017)

Tradisi Kupatan di Desa Alasmalang dilakukan dengan dua variasi bentuk ketupat, yaitu ketupat tumpeng dan ketupat debleng. Tetapi kedua variasi ketupat tersebut lebih dikenal sebagai ketupat bawang dan ketupat Jawa. Kedua variasi ketupat tersebut biasa dibuat oleh Ibu-Ibu di Desa Alasmalang pada masa Hari Raya Ketupat (Kupatan).

Dijelaskan oleh Dwi \& Farabi (2017), bahwa ketupat tumpeng atau dikenal sebagai ketupat bawang, merupakan ketupat yang bentuknya mengerucut dengan dasar melebar dan daun helai janur yang menjuntai di bagian runcing. 

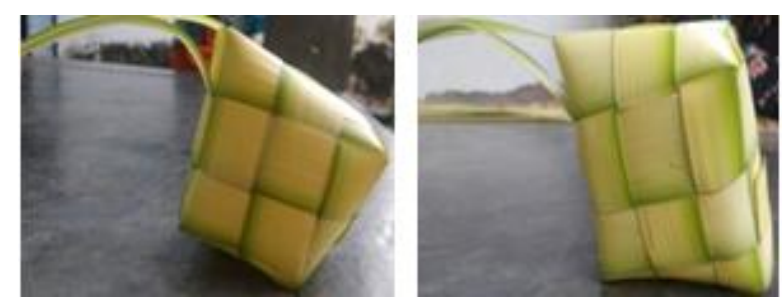

Gambar 3. Ketupat Bawang (Kiri) dan Ketupat Jawa (Kanan)

Sedangkan ketupat debleng atau dikenal sebagai ketupat Jawa, merupakan ketupat yang dibuat dari empat helai janur sehingga membentuk belah ketupat yang ujung janurnya keluar di dua sudut yang berseberangan.

Pendefinisian kedua ketupat tersebut menunjukkan bahwa pada ketupat memuat konsepkonsep matematika seperti bentuk geometris, konsep sudut, serta konsep garis. Konsep-konsep matematika tersebut tidak pernah disadari oleh pembuat ketupat. Namun dapat menjadi dasar yang menarik dalam proses pembelajaran guna memahamkan siswa terhadap konsep matematika.

Mathematics which practiced by cultural groups, such as urban and rural communities, groups of workers, professional classes, children in a given age group, indigenous societies, and so many other groups that are identified by the objectives and traditions common to these groups is called ethnomathematics (D'Ambrosio, 2001). Keberadaan konsep-konsep matematika dalam pembuatan ketupat merupakan hal yang menarik untuk diidentifikasi, yang selanjutnya dapat menjadi dasar dalam pembelajaran matematika kontekstual berbasis budaya.

Berbagai eksplorasi budaya (khususnya tentang makanan tradisional dan anyaman) serta identifikasi konsep matematika di dalamnya telah dilakukan oleh peneliti lain. Penelitian tersebut dilakukan di Banyuwangi maupun di luar Banyuwangi. Penelitian tentang jajan pasar di Yogyakarta menunjukkan adanya konsep segi empat, lingkaran, trapesium, elips, bola, tabung, balok, kerucut, serta pemodelan persamaan linear dua dan tiga variabel (Huda, 2018). Penelitian tentang makanan tradisional Bugis menunjukkan adanya konsep geometri khususnya bangun datar dan bangun ruang (Pathuddin \& Raehana, 2019) . Adapun penelitian yang dilakukan terhadap makanan tradisional Cilacap menunjukkan adanya konsep persegi, persegipanjang, segitiga, jajargenjang, trapesium, serta segi enam (Choeriyah, et al., 2020). Beberapa penelitian yang telah dilakukan menunjukkan adanya berbagai upaya mengkaji konsep-konsep matematika dalam makanan tradisional, namun belum dilakukan terhadap ketupat.
Pembuatan ketupat juga melibatkan proses menganyam janur menjadi kulit ketupat. Penelusuran yang dilakukan pada penelitian terdahulu diketahui bahwa kajian tentang etnomatematika pada anyaman belum pernah dilakukan pada anyaman kulit ketupat. Penelitian tentang kerajinan anyaman bambu di Desa Gintangan Banyuwangi menunjukkan adanya konsep pengukuran, bangun datar, dan bangun ruang (Fajar, Sunardi, \& Yudianto, 2018). Penelitian tentang kerajinan anyaman Bali menunjukkan adanya konsep teselasi (pengubinan) serta bangun datar yaitu persegipanjang dan persegi (Puspadewi \& Putra, 2014).

Penelusuran tentang penelitian terdahulu menjadi dasar dilakukannya eksplorasi dan identifikasi etnomatematika pada ketupat bawang dan ketupat Jawa di Desa Alasmalang Banyuwangi. Hasil yang didapatkan dari penelitian ini diharapkan dapat menjadi bahan pengembangan pembelajaran berbasis etnomatematika ketupat di Desa Alasmalang khususnya.

\section{Metode Penelitian}

Penelitian ini dilakukan secara kualitatif dengan pendekatan etnografi. Penelitian dilakukan di Desa Alasmalang Kecamatan Singojuruh Banyuwangi selama bulan September 2020. Desa Alasmalang dipilih sebagai daerah penelitian karena masih didiami oleh masyarakat Suku Using dan masih aktif melaksanakan tradisi kupatan setiap tahunnya.

Informan ditentukan sebanyak tiga orang dari Ibu-ibu di Desa Alasmalang yang sudah berpengalaman minimal 10 tahun dalam pembuatan ketupat. Data diperoleh melalui proses observasi dan wawancara. Peneliti merupakan instrumen utama penelitian, sedangkan instrumen pendukung yang digunakan adalah pedoman wawancara dan pedoman observasi.

Analisis data dilakukan sesuai proses dalam pendekatan etnografi yaitu dengan analisis domain dan analisis taksonomi (Spradley, 1979). Hasil analisis selanjutnya menjadi dasar dalam penemuan tema-tema budaya khususnya etnomatematika pada proses pembuatan ketupat bawang dan ketupat Jawa. 


\section{Hasil dan Pembahasan}

\subsection{Pembuatan Ketupat Bawang dan Ketupat Jawa}

Penelitian dilakukan di Dusun Krajan RT 01 RW 01 Desa Alasmalang karena informan tinggal di wilayah tersebut. Informan penelitian adalah tiga orang Ibu, yaitu A (berpengalaman membuat ketupat selama 31 tahun), B (berpengalaman membuat ketupat selama 23 tahun), serta C (berpengalaman membuat ketupat selama 42 tahun).

Ketiga informan mengawali proses pembuatan ketupat dengan mempersiapkan beras yang akan digunakan. Beras direndam antara 9 hingga 12 jam sebelum digunakan sebagai isian ketupat, kemudian dicuci kembali agar tidak berbau. Selama menunggu proses perendaman beras, informan melakukan pembuatan kulit ketupat.
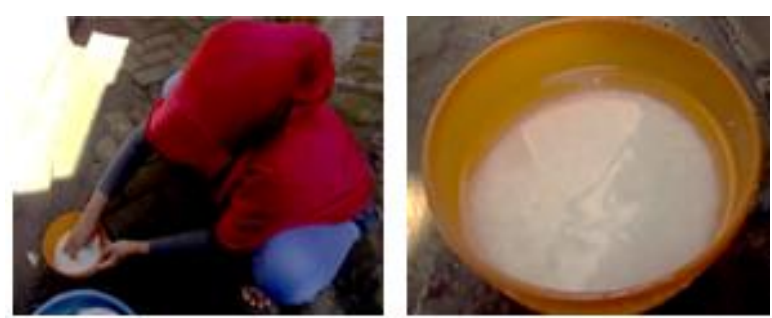

Gambar 4. Pencucian dan Perendaman Beras

Pembuatan kulit ketupat diawali dengan pemisahan tulang dari janur agar dapat dianyam. Proses pembuatan kulit ketupat bawang dilakukan dengan menggulung dua janur sebanyak 2 atau 3 putaran masing-masing di tangan kiri dan kanan.

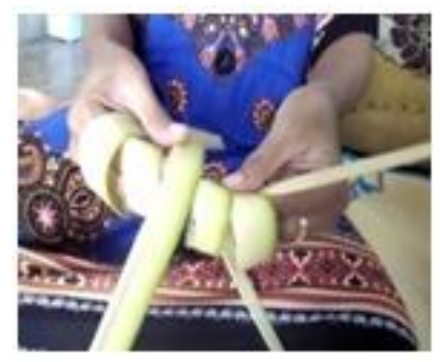

Gambar 5. Penggulungan Awal Kulit Ketupat Bawang

Untuk mempermudah pemahaman proses penganyaman digunakan istilah melewati bagian atas janur (selanjutnya disebut atas) dan melewati bagian bawah janur (selanjutnya disebut bawah). Janur dianyam dengan urutan atas - bawah - atas pada langkah pertama (gambar 6a), kemudian urutan bawah - atas - bawah pada langkah kedua (gambar 6b), dan urutan atas - bawah - atas pada langkah ketiga (gambar 6c). (a)
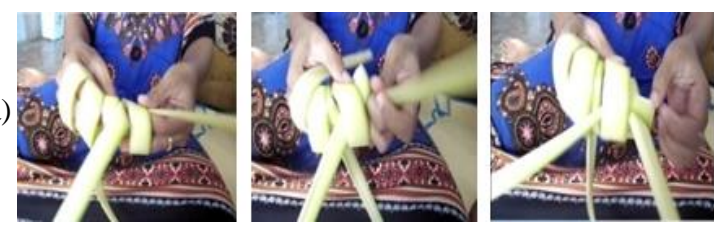

(b)
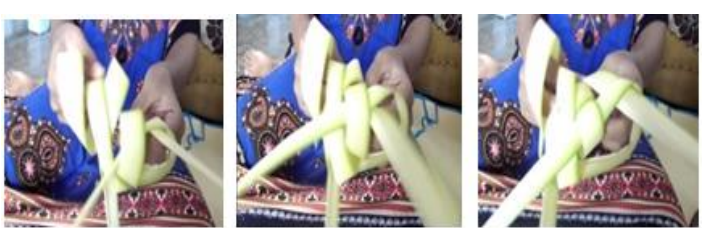

(c)
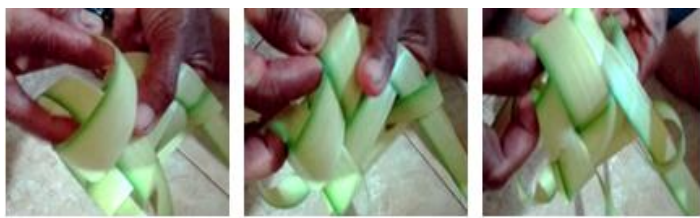

Gambar 6. Proses Penganyaman Ketupat Bawang

Proses menganyam dilakukan dari ujung atas janur secara bergantian sampai ke bawah, pangkal janur dianyam hingga ke atas, kemudian menganyam ujung janur secara bergantian hingga bertemu dengan ujung janur sebelumnya.
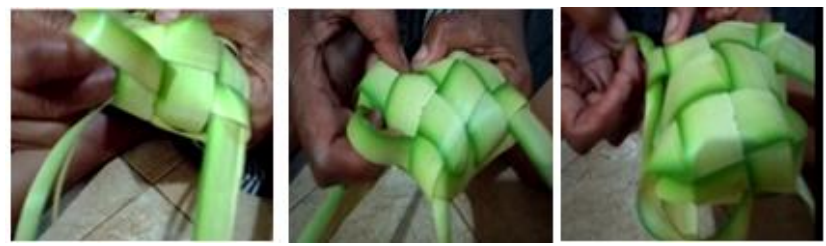

Gambar 7. Penganyaman dari Ujung Atas Janur Secara Bergantian Hingga ke Bawah
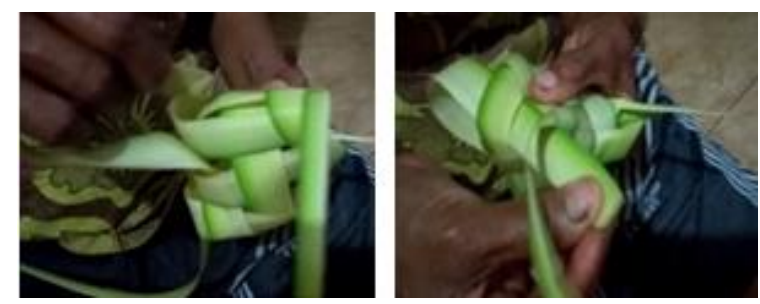

Gambar 8. Pangkal Janur Dianyam Secara Bergantian Hingga ke Atas

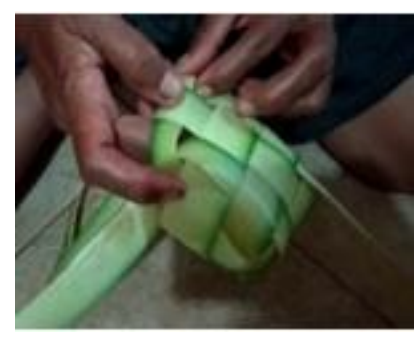

Gambar 9. Penganyaman Ujung Janur Hingga Bertemu Ujung Janur Sebelumnya

Sedangkan pangkal janur dianyam hingga bertemu dengan pangkal janur yang sebelumnya. 

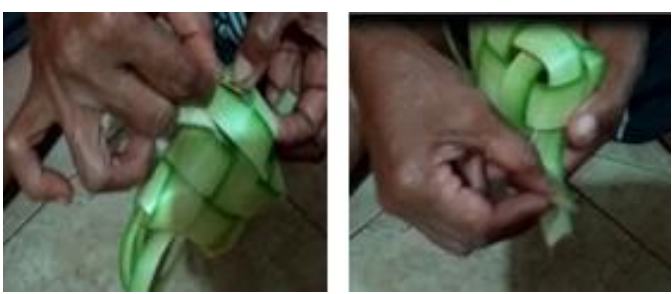

Gambar 10. Penganyaman Pangkal Janur Hingga Bertemu Pangkal Janur yang Sebelumnya

Setelah proses menganyam selesai, kedua pangkal dan kedua ujung janur dapat ditarik secara bersama berulang-ulang dengan tujuan agar anyaman lebih rapat. Selain itu dapat pula dilakukan cara menarik bagian-bagian anyaman yang terlihat kurang rapat sesuai alur anyamannya.
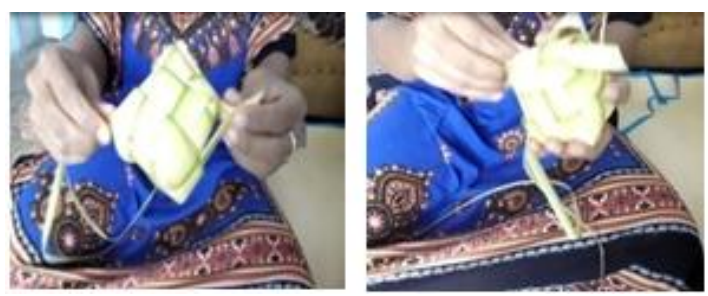

Gambar 11. Penarikan Kedua Ujung Janur atau Bagian Anyaman yang Kurang Rapat

Proses pembuatan kulit ketupat Jawa dilakukan dengan menggulung dua janur sebanyak 2 atau 3 putaran masing-masing di tangan kiri dan kanan.

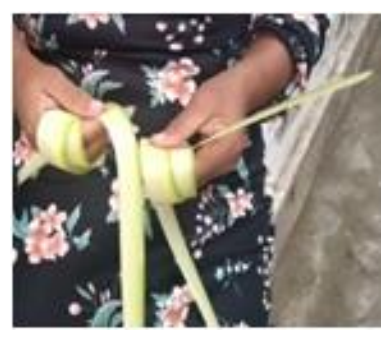

Gambar 12. Penggulungan Awal Kulit Ketupat Jawa

Janur dianyam dengan urutan atas - bawah atas pada langkah pertama (gambar 13a), kemudian urutan bawah - atas - bawah pada langkah kedua (gambar 13b), dan urutan atas bawah - atas pada langkah ketiga (gambar 13c).

(a)
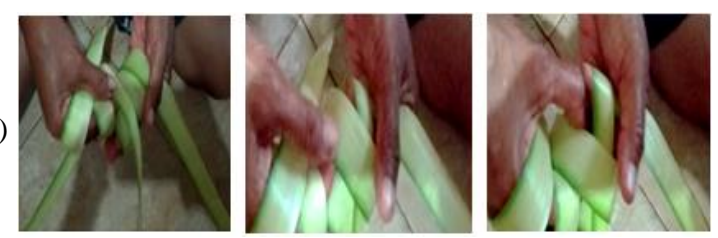

(b)
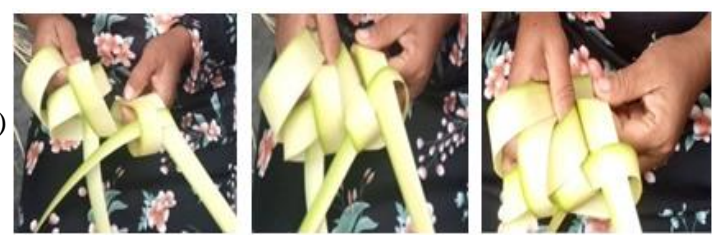

(c)
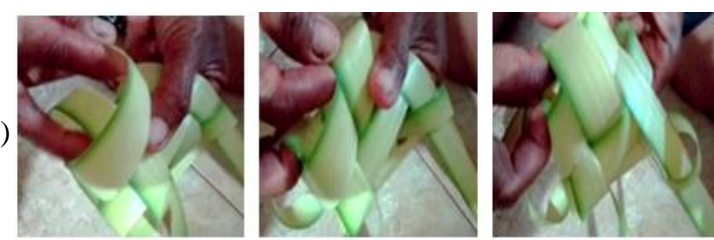

Gambar 13. Proses Penganyaman Ketupat Jawa

Proses menganyam dilakukan dari ujung janur atas diputar untuk dianyam secara bergantian hingga ke bawah, pangkal janur dianyam hingga ke atas, ujung janur dililitkan dengan pangkal janur pertama kemudian dianyam secara bergantian hingga bertemu dengan ujung janur yang sebelumnya. Sedangkan pangkal janur kedua dianyam secara bergantian hingga bertemu dengan pangkal janur yang sebelumnya.
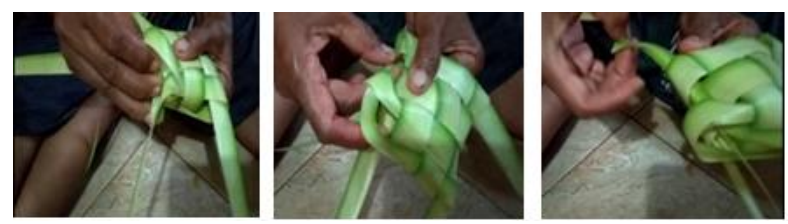

Gambar 14. Ujung Janur Atas Diputar untuk Dianyam Secara Bergantian Hingga ke Bawah
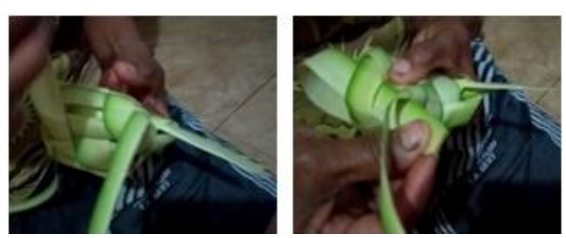

Gambar 15. Pangkal Janur Dianyam Secara Bergantian Hingga ke Atas
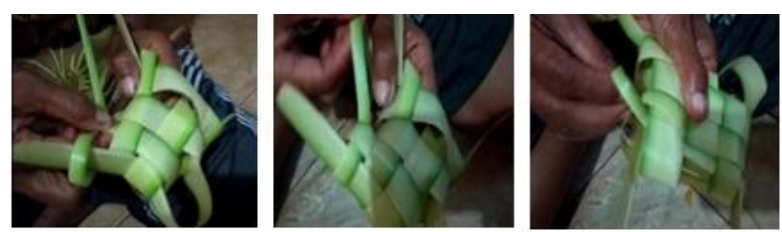

Gambar 16. Ujung Janur yang Diputar ke Pangkal Janur Lalu Dianyam secara bergantian Hingga Bertemu Ujung Janur Sebelumnya
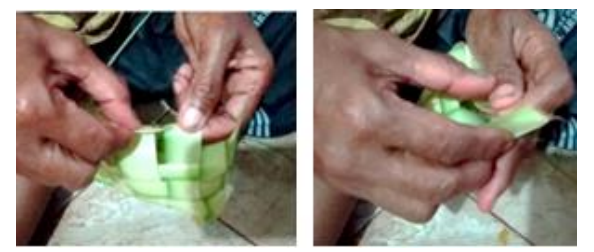

Gambar 17. Penganyaman Pangkal Janur Hingga Bertemu Pangkal Janur yang Sebelumnya

Kedua pangkal dan kedua ujung janur ditarik secara bersama berulang-ulang agar anyaman menjadi lebih rapat. Proses tersebut dapat juga dilakukan dengan menarik bagian anyaman yang kurang rapat mengikuti alur anyaman. 


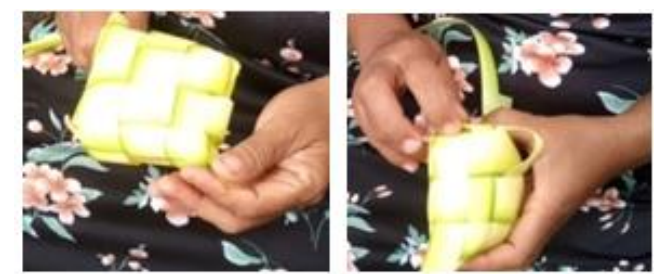

Gambar 18. Penarikan Kedua Ujung Janur atau Bagian Anyaman yang Kurang Rapat
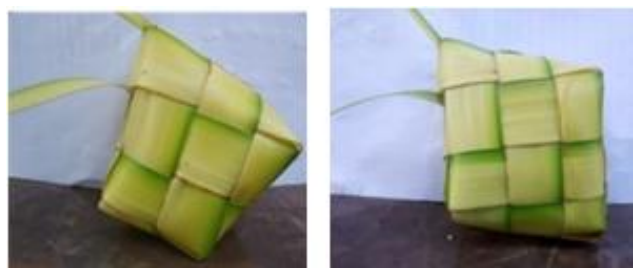

Gambar 19. Kulit Ketupat Bawang (Kiri) dan Ketupat Jawa (Kanan)

Jika semua kulit ketupat telah selesai dibuat selanjutnya kulit dicuci hingga bersih, kemudian diisi dengan beras yang telah direndam dan dicuci kembali sebanyak $\frac{1}{2}$ bagian dari kulit ketupat.
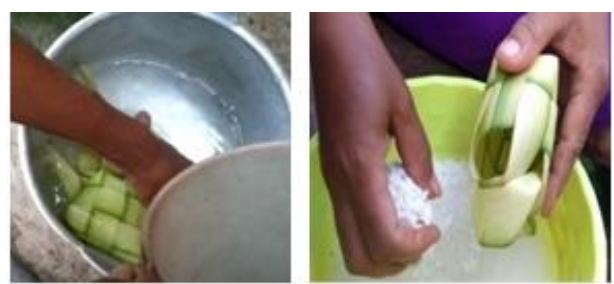

Gambar 20. Pencucian dan Pengisian Kulit Ketupat dengan Beras

Setelah semua kulit ketupat terisi dengan beras, dilakukan proses memasak ketupat. Ketupat dimasak selama 2 hingga 3 jam, jika beras yang digunakan telah direndam dalam waktu semalam. Sedangkan jika beras tidak direndam dalam waktu semalam, maka informan menambahkan waktu memasak sebanyak 30 menit hingga 1 jam.

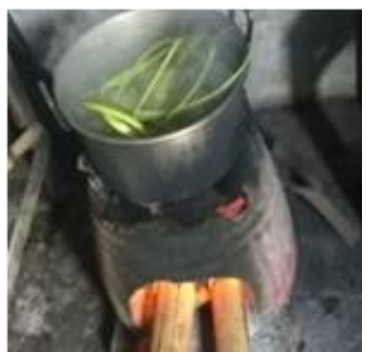

Gambar 21. Proses Merebus Ketupat

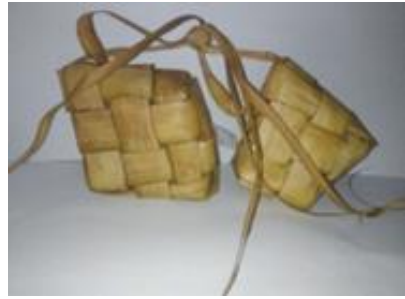

Gambar 22. Ketupat Jawa (Kiri) dan Ketupat Bawang (Kanan) yang Sudah Matang
Berdasarkan hasil eksplorasi yang diperoleh dapat ditentukan hasil analisis domain seperti pada tabel 1 berikut.

Tabel 1. Analisis Domain

\begin{tabular}{cll}
\hline Objek & \multicolumn{1}{c}{ Domain } \\
\hline \multirow{2}{*}{ Ketupat Bawang } & 1. Proses Pembuatan \\
Ketupat Jawa & 2. Bentuk Ketupat \\
& \multicolumn{2}{c}{$\begin{array}{l}\text { Proses Pengisian Kulit } \\
\text { Ketupat }\end{array}$} \\
\hline
\end{tabular}

Hasil analisis domain pada tabel 1 menjadi dasar analisis taksonomi seperti pada tabel 2 berikut.

Tabel 2. Analisis Taksonomi

\begin{tabular}{lccc}
\hline \multicolumn{1}{c}{ Konsep Matematika } & \multicolumn{3}{c}{ Domain } \\
\cline { 2 - 4 } & $(1)$ & $(2)$ & $(3)$ \\
\hline Hubungan antara Dua Garis & $\sqrt{ }$ & & \\
Sudut & $\sqrt{ }$ & $\sqrt{ }$ & \\
Bangun Datar & $\sqrt{ }$ & $\sqrt{ }$ & \\
Bangun Ruang & & $\sqrt{ }$ & \\
Pengubinan & & $\sqrt{ }$ & \\
Pecahan & & & $\sqrt{ }$ \\
Volume Bangun Ruang & & & $\sqrt{ }$ \\
dengan Satuan Tidak Baku & & & \\
\hline
\end{tabular}

\subsection{Penemuan Tema Budaya}

Pembuatan ketupat merupakan bagian dari tradisi masyarakat muslim di Indonesia. Di Desa Alasmalang Kecamatan Singojuruh Banyuwangi, tradisi kupatan masih aktif dilakukan setiap tahun pada hari ketujuh bulan Syawal. Ketupat yang biasa dibuat adalah jenis ketupat bawang dan ketupat Jawa.

Pada proses pembuatan ketupat bawang dan ketupat Jawa menunjukkan adanya bentuk janur yang diposisikan sejajar, berpotongan, atau berimpit.

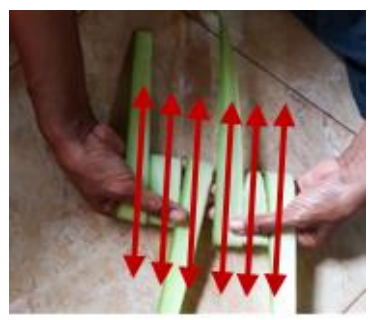

Gambar 23. Posisi Awal Janur Sebelum Dianyam
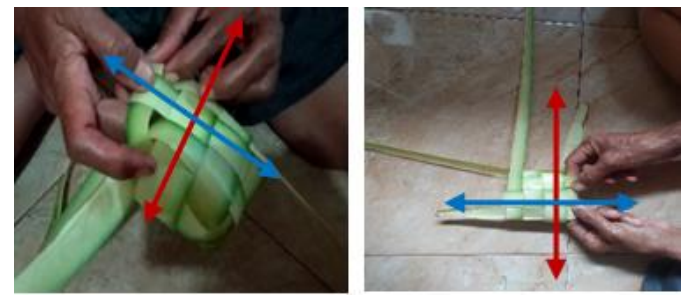

Gambar 24. Proses Menganyam dengan Memotongkan Antar Posisi Janur 

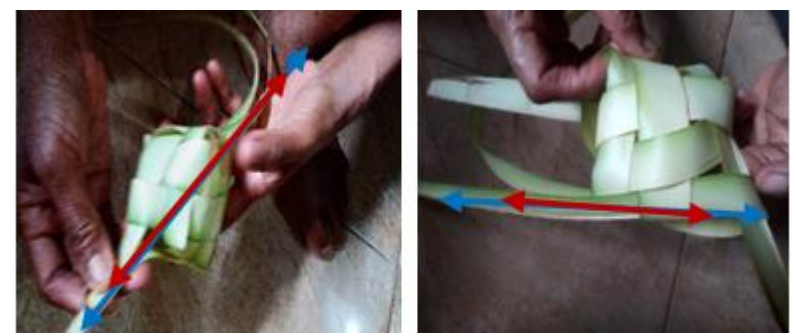

Gambar 25. Proses Menganyam dengan Mengimpitkan Posisi Janur

Ketiga posisi pada gambar 23, 24, dan 25 menunjukkan adanya hubungan antara dua garis dalam posisi sejajar, berpotongan, dan berimpit. Hal ini sesuai dengan konsep tentang hubungan antar garis, yaitu : (1) dua garis dikatakan sejajar jika dan hanya jika kedua garis tersebut sebidang dan tidak berpotongan; (2) dua garis dikatakan berpotongan jika dan hanya jika kedua garis tersebut mempunyai tepat satu titik persekutuan (Susanah \& Hartono, 2009); dan (3) dua garis dikatakan berimpit jika dan hanya jika terdapat satu garis yang menjadi tempat terletaknya garis yang lain (As'ari, et al., 2017).

Posisi janur pada proses pembuatan ketupat bawang dan ketupat Jawa menunjukkan adanya persilangan yang membentuk suatu sudut.
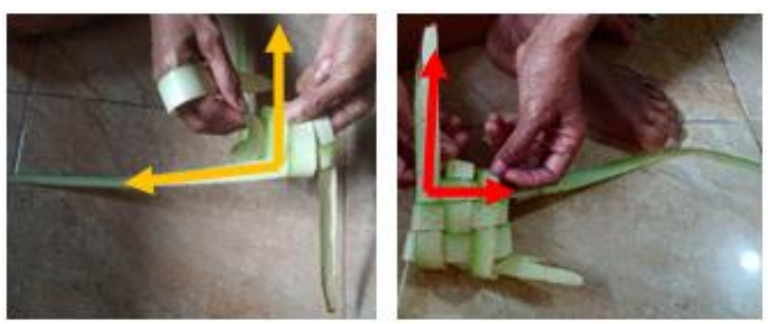

Gambar 26. Perpotongan Dua Janur yang Membentuk Sudut Siku-Siku

Suatu sudut dikatakan siku-siku jika dan hanya jika memiliki ukuran 90 (Susanah \& Hartono, 2009). Perpotongan setiap janur menunjukkan adanya bentuk segiempat beraturan, yaitu persegi.
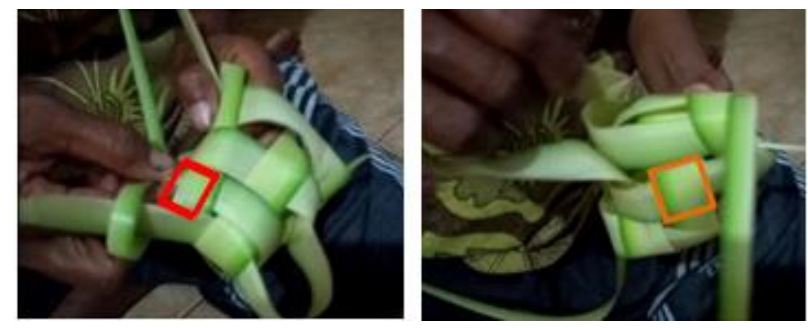

Gambar 27. Perpotongan Dua Janur yang Membentuk Persegi

Persegi merupakan segiempat yang mempunyai dua pasang sisi berhadapan saling sejajar, semua sudut sama besar, dan semua sisi sama panjang (As'ari, et al., 2017).
Proses pembuatan ketupat bawang juga menunjukkan adanya bentuk segiempat tidak beraturan seperti pada gambar 28 berikut.

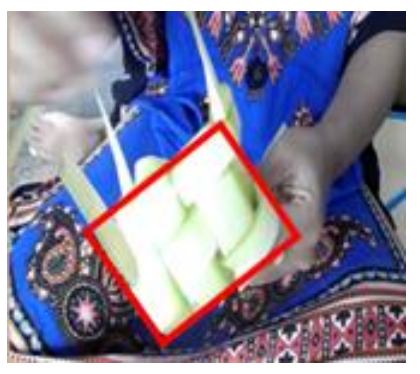

Gambar 28. Perpotongan Dua Janur yang Membentuk Segiempat Tidak Beraturan

Segiempat tidak beraturan merupakan segiempat yang tidak memiliki sudut yang sama besar dan sisi yang tidak sama panjang (Negoro \& Harahap, 1998).

Kulit ketupat bawang yang dihasilkan juga menunjukkan permukaan dengan bentuk segiempat tidak beraturan seperti pada gambar 29 berikut.

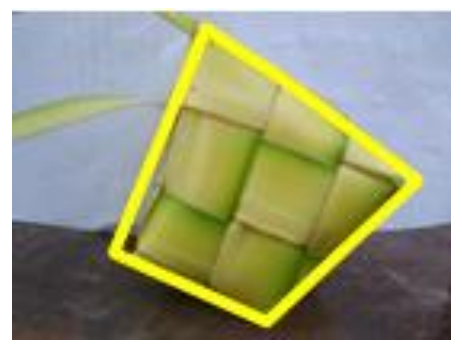

Gambar 29. Bentuk Segiempat Tidak Beraturan pada Ketupat Bawang

Sedangkan pada kulit ketupat Jawa menunjukkan permukaan dengan bentuk belah ketupat. Hal ini ditunjukkan dengan panjang sisi yang sama dari ketupat Jawa, panjang diagonal sama, serta sudut yang berseberangan sama besar.
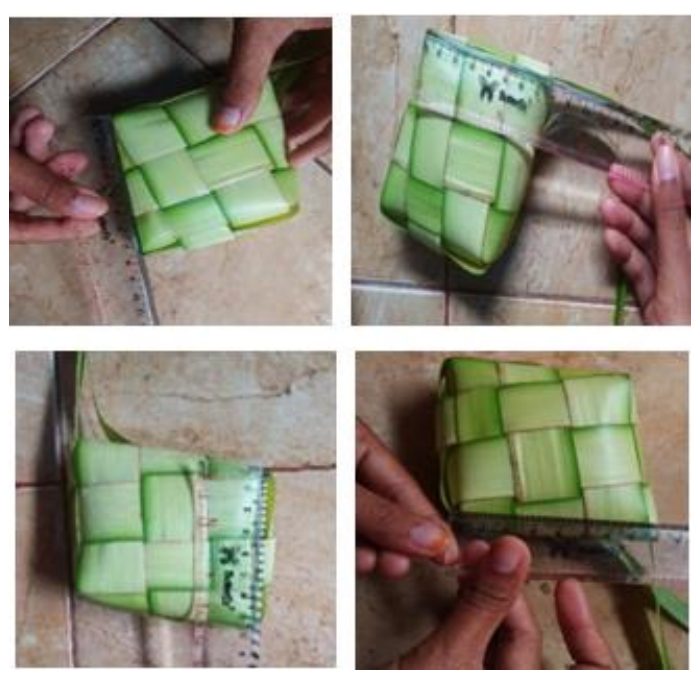

Gambar 30. Pengukuran Panjang Sisi Ketupat Jawa 

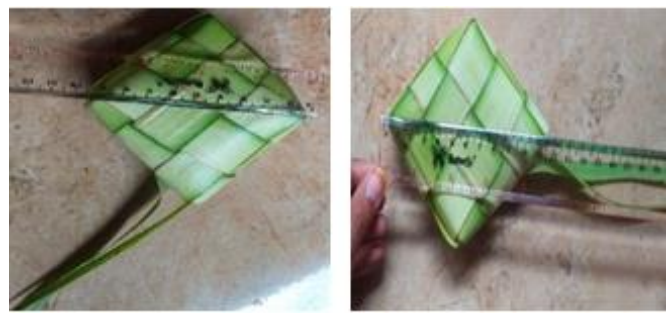

Gambar 31. Pengukuran Panjang Diagonal Ketupat Jawa
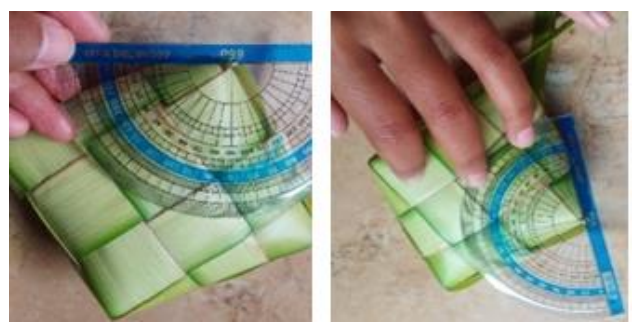

Gambar 32. Pengukuran Sudut Ketupat Jawa

Belah ketupat merupakan segiempat yang memiliki dua pasang sisi berhadapan sejajar yang masing-masing pasangan sama panjang, sudutsudut yang berhadapan sama besar (As'ari, et al., 2017).

Pada ketupat bawang dan ketupat Jawa dapat dilakukan pengukuran sudut. Sudut yang diperoleh pada ketupat bawang dan ketupat Jawa adalah sudut tumpul dan sudut lancip.
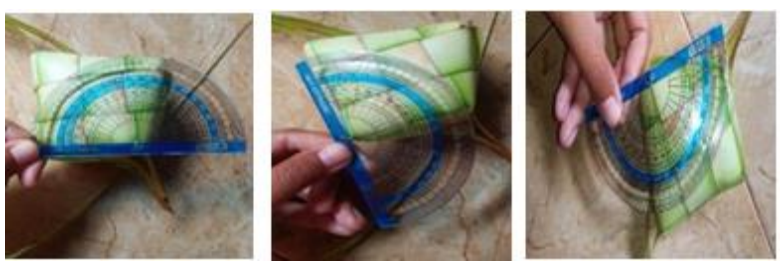

Gambar 33. Sudut Tumpul pada Ketupat Bawang

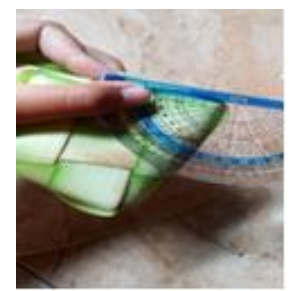

Gambar 34. Sudut Lancip pada Ketupat Bawang
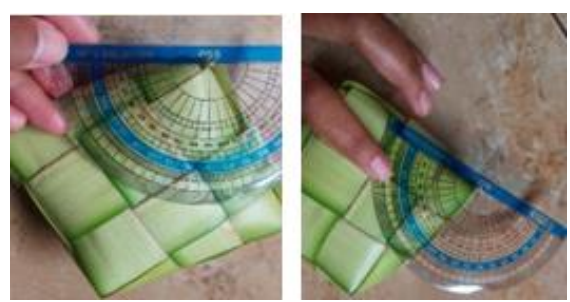

Gambar 35. Sudut Tumpul (Kiri) dan Sudut Lancip (Kanan) pada Ketupat Jawa

Suatu sudut dikatakan sudut tumpul jika dan hanya jika berukuran lebih dari 90 tetapi kurang dari 180, sedangkan sudut dikatakan lancip jika dan hanya jika berukuran lebih dari 0 dan kurang dari 90 (Susanah \& Hartono, 2009). Pada gambar 39, pengukuran sudut Ketupat Jawa masingmasing hanya dilakukan satu kali karena setiap sudut yang berhadapan memiliki besar yang sama, sesuai dengan pemahaman dalam belah ketupat.

Ketupat bawang menunjukkan adanya bentuk bangun ruang yang tidak beraturan. Sedangkan ketupat Jawa menunjukkan adanya bentuk bangun ruang prisma segiempat.

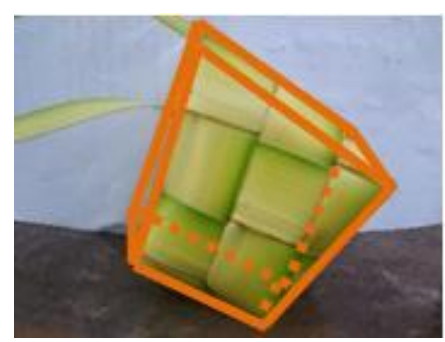

Gambar 36. Bentuk Bangun Ruang Tidak Beraturan pada Ketupat Bawang

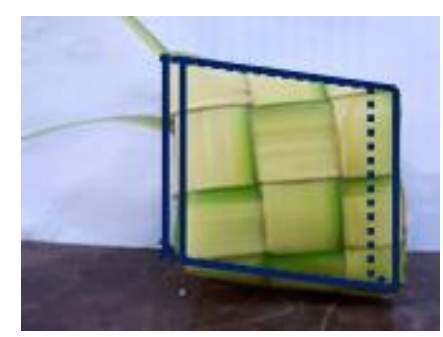

Gambar 37. Bentuk Bangun Ruang Prisma Segiempat pada Ketupat Jawa

Prisma segiempat adalah polihedron yang memiliki dua pasang sisi sejajar dan semua sisi yang lain sejajar dengan sebuah garis yang memotong pemuat kedua sisi yang sejajar itu (Susanah \& Hartono, 2009).

Pada ketupat bawang dan ketupat Jawa juga diketahui memuat pola pengubinan yang teratur seperti pada gambar 38 berikut.
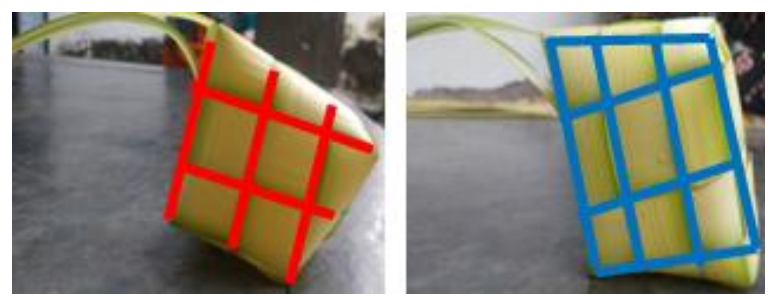

Gambar 38. Pola Pengubinan pada Ketupat Bawang (Kiri) dan Ketupat Jawa (Kanan)

Proses pengisian kulit ketupat dilakukan dengan memasukkan beras yang telah direndam dan dicuci kembali sebanyak $\frac{1}{2}$ bagian kulit ketupat. Proses tersebut menunjukkan adanya konsep pecahan dan penggunaan satuan tidak baku dalam penentuan volume bangun ruang. Volume beras tersebut dapat dikonversikan ke satuan baku seperti pada gambar 39 dan 40 berikut. 


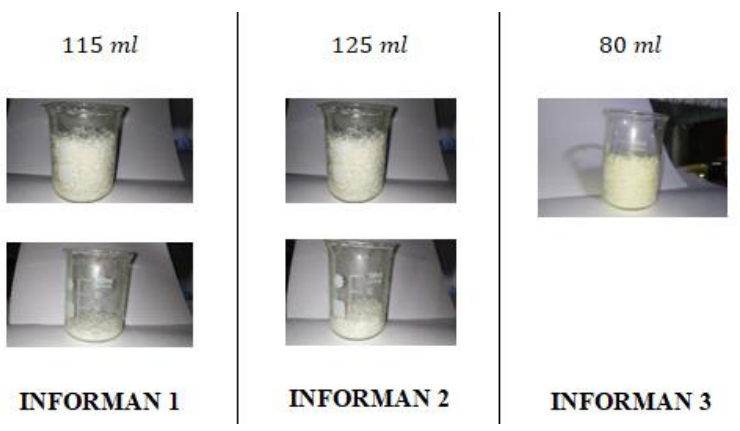

Gambar 39. Konversi Banyak Beras pada Ketupat Bawang

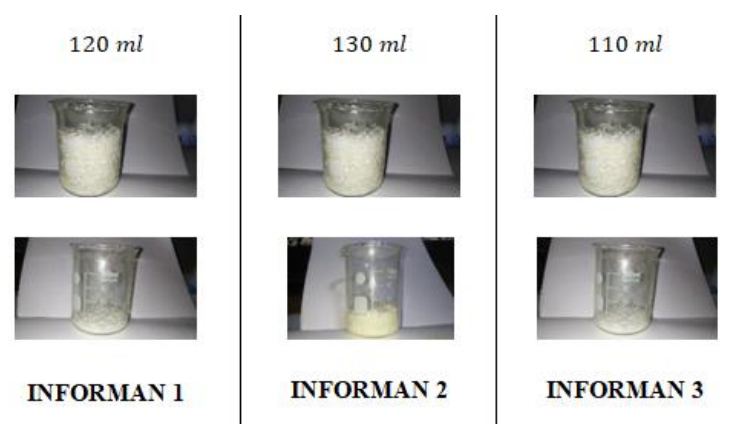

Gambar 40. Konversi Banyak Beras pada Ketupat Jawa

Sedangkan pecahan ditunjukkan dari proses pengisian beras yang diperkirakan hanya setengah bagian dari isi dalam kulit ketupat.

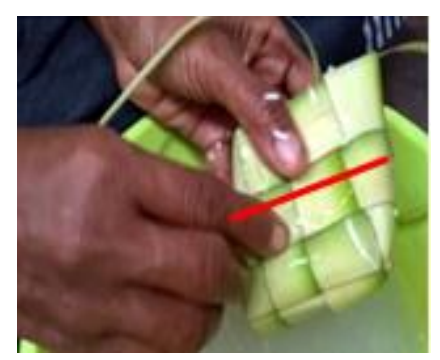

Gambar 41. Pengisian Setengah Bagian Kulit Ketupat

Tema budaya yang dapat diidentifikasi dari ketupat bawang dan ketupat Jawa di Desa Alasmalang Banyuwangi menunjukkan bahwa ketupat merupakan salah satu budaya di Banyuwangi yang menarik untuk dieksplorasi. Masyarakat Banyuwangi memiliki berbagai bentuk seni budaya dan adat istiadat berbasis etnik; baik budaya asli, hasil akulturasi budaya, juga tradisi budaya yang tak terpisahkan dengan nilai kepercayaan (Makmur \& Taufiq, 2016).

Etnomatematika merupakan bagian dari hasil eksplorasi budaya yang menunjukkan adanya beragam konsep matematika yang sering tidak disadari oleh pelaku budaya tersebut. Sehingga, etnomatematika dapat digunakan sebagai petunjuk untuk lebih memahami budaya (Shirley, 2015). Sehingga keberadaan etnomatematika dapat memperkuat akar pemahaman matematika melalui proses mengetahui dan mengasimilasi budaya yang dominan selama akar budaya yang dimiliki cukup kuat (D'Ambrosio, 2001).

Selain itu etnomatematika yang diidentifikasi dari suatu budaya dapat menjadi sumber dalam pembelajaran matematika, menambah wawasan siswa tentang keberadaan matematika pada budaya yang dimiliki, meningkatkan motivasi belajar, serta memfasilitasi siswa dalam mengaitkan konsep yang dipelajari dengan kondisi nyata (Prabawati, 2016). Untuk itu penelitian ini masih perlu dikembangkan lagi guna mengaplikasikan berbagai tema budaya yang telah ditemukan dalam ketupat bawang dan ketupat Jawa tersebut.

\section{Kesimpulan}

Ketupat merupakan makanan khas yang dikenal sebagian besar masyarakat di berbagai wilayah di Indonesia. Banyuwangi, khususnya Desa Alasmalang, masih aktif membuat ketupat salah satunya pada hari ketujuh hari raya Idul Fitri. Ketupat memuat konsep-konsep matematika diantaranya: hubungan antar garis (sejajar, berpotongan, dan berimpit), sudut (siku-siku, lancip, dan tumpul), bangun datar (persegi, segiempat tidak beraturan, dan belah ketupat), bangun ruang (prisma segiempat beraturan dan tidak beraturan), pengubinan, pecahan $\left(\frac{1}{2}\right)$, serta volume bangun ruang dengan satuan tidak baku. Konsep-konsep matematika yang dapat diidentifikasi dalam bentuk dan proses pembuatan ketupat dapat diintegrasikan dalam proses pembelajaran, khususnya dengan konsep kontekstual. Hal ini akan menjadi dasar pengembangan penelitian berikutnya.

\section{Daftar Pustaka}

Amin, W. R. (2017). Kupatan, Tradisi untuk Melestarikan Ajaran Bersedekah, Memperkuat Tali Silaturahmi, dan Memuliakan Tamu. Al'A'raf, Jurnal Pemikiran Islam dan Filsafat, Vol. XIV, No. 2 , 267-282.

Arif, M., \& Lasantu, M. Y. (2019). Nilai Pendidikan dalam Tradisi Lebaran Ketupat Masyarakat Suku Jawa Tondano di Gorontalo. Madani, Vol. 1, No. $2,144-159$.

As'ari, A., Tohir, M., Valentino, E., Imron, Z., \& Taufiq, I. (2017). Matematika SMP/MTs Kelas VII Semester 2. Jakarta: Pusat Kurikulum dan Perbukuan, Balitbang, Kemendikbud.

Choeriyah, L., Nusantara, T., Qohar, A., \& Subanji. (2020). Studi etnomatematika pada makanan 
tradisional Cilacap. AKSIOMA: Jurnal Matematika dan Pendidikan Matematika, Vol. 11, No. 2 , 210-218.

D'Ambrosio, U. (2001). Ethnomathematics, Link between Traditions and Modernity. Rotterdam, The Netherlands: Sense Publisher.

Djojosuroto, K. (2013). Ikon Tradisi Ba'do Katupat Sebagai Refleksi Kebudayaan Masyarakat Jaton di Sulawesi Utara. el Harakah Vol.15, No.2 , 217-227.

Dwi, A. A., \& Farabi, Z. A. (2017, Oktober 3). Detik food. Dipetik November 10, 2020, dari Detik.com: https://food.detik.com/infografis/d3668651/mengenal-bentuk-bentuk-ketupattradisional-indonesia

Fajar, F. A., Sunardi, \& Yudianto, E. (2018). Etnomatematika Pembuatan Kerajinan Tangan Anyaman Bambu Masyarakat Osing di Desa Gintangan Banyuwangi sebagai Bahan Ajar Geometri. Kadikma, Vol. 9, No. 3 , 97-108.

Huda, N. T. (2018). Etnomatematika Pada Bentuk Jajanan Pasar di Daerah Istimewa Yogyakarta. JNPM (Jurnal Nasional Pendidikan Matematika), Vol. 2, No. 2 , 217-232.

Makmur, M. H., \& Taufiq, A. (2016). Konstruksi Kebijakan Kebudayaan di Banyuwangi: Wacana, Relasi, dan Model Kebijakan Berbasis Identitas. Dalam N. Anoegrajekti, S. Macaryus, \& H. Prasetyo, Kebudayaan Using: Konstruksi, Identitas, dan Pengembangannya (hal. 102-120). Jember: Pusat Penelitian Budaya Etnik dan Komunitas, Lembaga Penelitian Universitas Jember.

Negoro, S., \& Harahap, B. (1998). Ensiklopedia Matematika (edisi kedua). Surabaya: Ghalia Indonesia.
Pathuddin, H., \& Raehana, S. (2019). Etnomatematika : Makanan Tradisional Bugis sebagai Sumber Belajar Matematika. MaPan : Jurnal Matematika dan Pembelajaran, Vol. 7, No. 2 , 307-327.

Prabawati, M. N. (2016). Etnomatematika Masyarakat Pengrajin Anyaman Rajapolah Kabupaten Tasikmalaya. Infinity, Vol 5, No. 1 , 25-31.

Puspadewi, K. R., \& Putra, I. G. (2014). Etnomatematika di Balik Kerajinan Anyaman Bali. Jurnal Matematika, Vol. 4, No. 2 , 80-89.

Rahmadi, I., Sugiyono, \& Suyatma, N. E. (2019). Teknologi Pengolahan Ketupat: Perubahan Karakteristik Fisikokimia dan Mikrobiologi selama Pengolahan dan Penyimpanan. PANGAN, Vol. 28, No. 2 , 161-170.

Rianti, A., Novenia, A. E., Christopher, A., Lestari, D., \& Parassih, E. K. (2018). Ketupat as traditional food of Indonesian culture. Journal of Ethnic Foods Vol. 5 , 4-9.

Shirley, L. (2015). Mathematics of Students' Culture: a Goal of Localized Ethnomathematics. Revista Latinoamericana de Etnomatematica, Vol. 8, No. $2,316-325$.

Spradley, J. P. (2007). Metode Etnografi. Yogyakarta: Tiara Wacana.

Susanah, \& Hartono. (2009). Geometry (edisi keempat). Surabaya: Unesa University Press.

Yanti, F. (2019). Komunikasi Sosial dalam Membangun Komunikasi Umat (Kajian Makna Tradisi Ied (Lebaran) pada masyarakat Muslim di Bandar Lampung). Komunika, Vol. 2, No. 1 , 1-16. 